\title{
Cultivar Resistance against Colletotrichum asianum in the World Collection of Mango Germplasm in Southeastern Brazil
}

\author{
Alessandro Vitale ${ }^{1, *}$, Acelino Couto Alfenas ${ }^{2}(0)$, Dalmo Lopes de Siqueira ${ }^{3}$, Donato Magistà ${ }^{4}$, \\ Giancarlo Perrone ${ }^{4}$ and Giancarlo Polizzi ${ }^{1}$ \\ 1 Dipartimento di Agricoltura, Alimentazione e Ambiente, Università di Catania, 95123 Catania, Italy; \\ gpolizzi@unict.it \\ 2 Laboratory of Forest Pathology/Bioagro, Departamento de Fitopatologia, Universidade Federal de Viçosa, \\ Viçosa 36570-900, Brazil; aalfenas@ufv.br \\ 3 Departamento de Fitotecnia, Universidade Federal de Viçosa, Viçosa 36570-900, Brazil; siqueira@ufv.br \\ 4 Istituto di Scienze delle Produzioni Alimentari, Consiglio Nazionale delle Ricerche (ISPA-CNR), 70126 Bari, \\ Italy; donato.magista@ispa.cnr.it (D.M.); giancarlo.perrone@cnr.it (G.P.) \\ * Correspondence: alevital@unict.it
}

Received: 14 January 2020; Accepted: 31 January 2020; Published: 2 February 2020

\begin{abstract}
During the spring of 2014, a wide survey was conducted in one of the most important mango (Mangifera indica) cultivating areas located in Minas Gerais State (Brazil) to ascertain the causal agent of severe anthracnose infections and to evaluate disease susceptibility within a world collection of mango germplasm. Overall, 86 cultivars were monitored and 152 fungal isolates recovered from infected samples were identified by morphological characterization, DNA sequencing and phylogenetic analyses. All isolates were identified as Colletotrichum asianum. Under natural disease pressure, it has been possible to ascertain a variable tolerance degree within the germplasm collection. By applying a categorized classification, cultivars were classified as follows: 10 highly sensitive (11.6\%), 13 sensitive (15.1\%), 18 moderately sensitive (20.9\%), 23 moderately tolerant $(26.7 \%)$, 11 tolerant $(12.8 \%)$, and 11 highly tolerant $(10.4 \%)$. The most susceptible cultivars to anthracnose were Ubà, Quinzenga, Amarelinha da Sementeira followed by Aroeira and Correjo, whereas Mallika followed by Ourinho and Lita resulted in the least susceptible cultivars. To the authors' knowledge, this is the first large-scale evaluation of mango susceptibility to $C$. asianum infections within a wide number of cultivars. Anthracnose is a serious threat to mango production and assessment of cultivar response to disease could be useful in breeding programs.
\end{abstract}

Keywords: anthracnose; Mangifera indica; morphological characterization; phylogenetic analyses; disease tolerance

\section{Introduction}

Mango (Mangifera indica L.) is the predominant tropical fruit in the world being cultivated in more than one hundred countries and accounting for more than half of global major tropical fruit production [1]. Currently, about $80 \%$ of global production is concentrated in nine nations. Brazil is the 7th largest producer in the world [2]. Mango is sometimes referred to as the king of the fruits, due to its eye-catching color, pleasant taste, the existence of higher concentrations of carotenoids, ascorbic acid and phytochemicals [3]. About $80 \%$ of the commodity is consumed as such; while $20 \%$ is processed into value-added products, such as mango puree, nectar, pickles, chutneys and canned products [4]. Unfortunately, infections caused by several pathogen species belonging to the Colletotrichum genus 
represent the most serious threat for mango cultivation worldwide. Disease caused by these fungal pathogens can negatively impact both yield and fruit quality $[5,6]$.

Up to 2009 Colletotrichum gloeosporioides s. lat. had been considered the main causal agent of mango anthracnose followed to lesser extent by $C$. acutatum [5-8]. Since the multi-gene phylogenetic analysis and poly-phasic approach were adopted, the ability to distinct phylogenetic (cryptic) species within Colletotrichum genus [9-14], including C. gloeosporioides [14-20] was strongly improved. Taxonomic revisions have resulted in the identification of several new species that include $C$ asianum, $C$. dianesei, $C$. fructicola, C. siamense, C. tropicale and C. karstii that are pathogenic on mango [14,21-24]. Other species belonging to $C$. acutatum s. lat. are also know to cause anthracnose on mango plantations.

Infections result in irregularly shaped, black necrotic spots on upper and lower leaf surfaces. Lesions frequently coalesce to form large necrotic areas, and severely infected leaves often curl. Leaf spots develop mainly on young tissue whereas in senescent leaf tissues the infections are not visible and the fungus remains dormant (latent infections). Symptoms can sometimes be observed as twig dieback, stalk lesions and flower blight. Although many portions of the plant may be infected, the major losses occur during ripening and in postharvest when brown or black lesions developed on fruit surfaces $[5,25,26]$.

Among all these species C. asianum is one of the most common and representative species associated with mango anthracnose, being reported from Australia, Brazil, China, Colombia, Ghana, India, Japan, Malaysia, Mexico, Panama, Philippines, South Africa, Sri Lanka, Thailand and Florida [14, $18,20-22,27-32]$.

The objectives of this study were: (i) to identify the Colletotrichum spp. associated with mango anthracnose using morphological, molecular characterization and multi-gene phylogenetic analysis; (ii) to compare the susceptibility of cultivars in southeastern Brazil to anthracnose infections; and (iii) to identify the cultivars representative in each of the susceptibility groups. Phenotypic evaluation of susceptibility to the pathogen under field conditions could be very useful for the selection of mango cultivars by farmers, technicians, and breeders.

\section{Results}

\subsection{Morphological Characterization}

A total of 152 monoconidial Colletotrichum isolates were collected from all evaluated mango cultivars showing leaf symptoms different in disposal, size and shape on the leaf blade (Figure 1A-E). Colonies grown on PDA were at first white-orange, then turned to greenish-grey to dark green at the center with the age. On the reverse side, colonies appear dark green at the center. The mean daily growth rate at $25^{\circ} \mathrm{C}$ ranged from 4.0 to $5.1 \mathrm{~mm}$. Colonies produced aerial mycelium in small tufts, white, sparse, with orange to dark orange conidial masses. The length and width of conidia produced by Colletotrichum isolates ranged from 10.5 to $19.7 \mu \mathrm{m}$ and 3.2 to $4.5 \mu \mathrm{m}$, respectively, and they were common in mycelium and conidial masses. They were one-celled, smooth-walled, guttulate, hyaline, cylindrical with obtuse ends (oblong) with slight narrowing at the center (Figure 1F-I). Sclerotia, acervuli and setae were absent in culture. All these characteristics are in accordance to those reported for C. asianum [33]. 


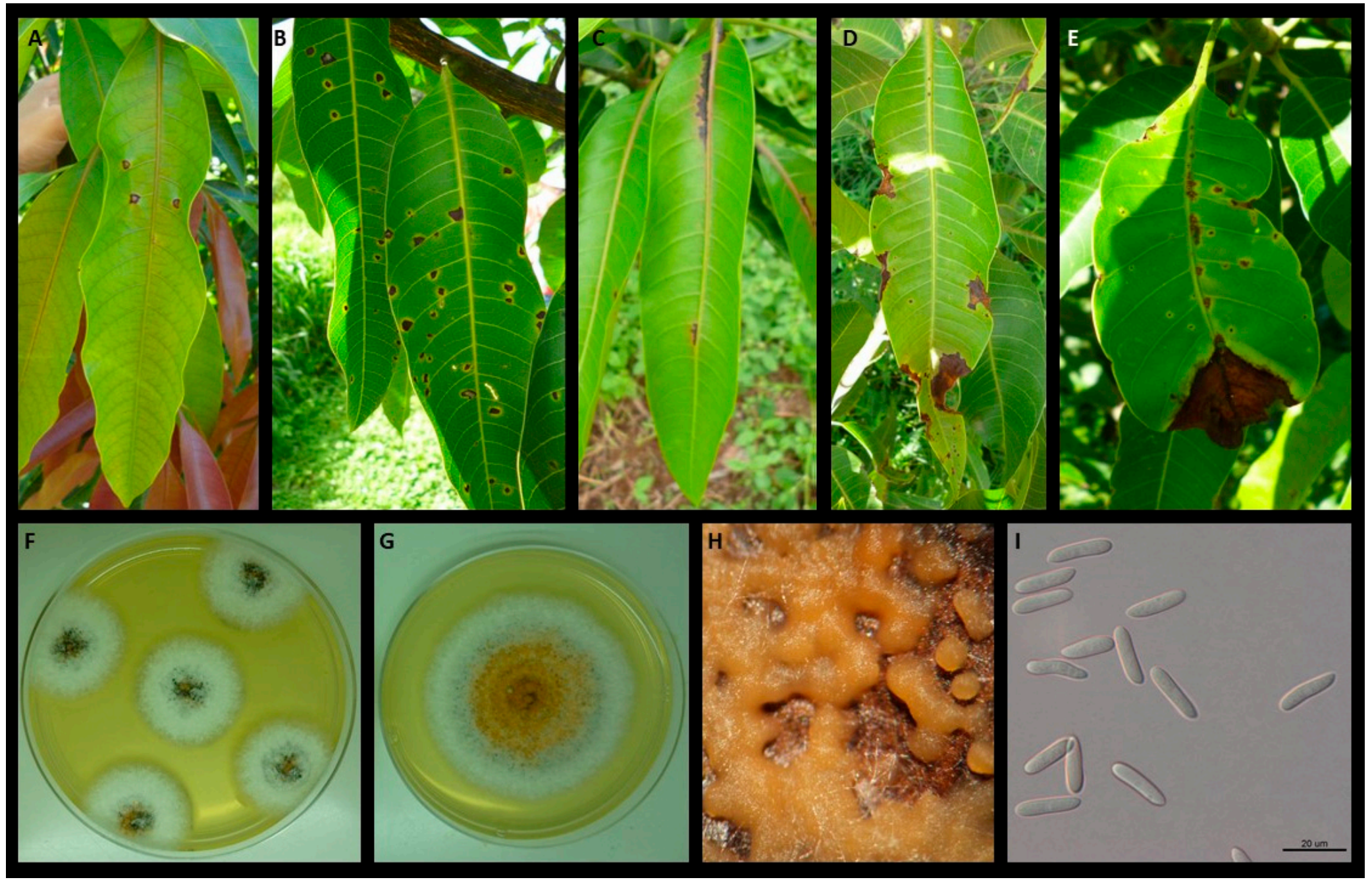

Figure 1. Variability in disposal, patterns and size on leaf blade of anthracnose infections caused by Colletotrichum asianum during susceptibility mango evaluation at the Sementeira Farm, Universidade Federal de Viçosa (A-E). Culture characteristics and microscopic features of the C. asianum: colony morphology from isolation attempts (F), 10-day-old monoconidial isolate (G), conidiomata on host tissues $(\mathbf{H})$ and conidia $(\mathbf{I})$. 


\subsection{Phylogenetic Analysis}

From the phylogenetic analysis of the tree loci (ITS, TUB, HIS) considered in this study, all of the 82 Colletotrichum isolates, randomly selected from 152 isolates previously morphologically characterized, belong to $C$. asianum. Two other species (C. aeschynomenes and $C$. salsolae) of the C. gloeosporioides clade musae, were not included in the tree loci phylogeny, since no HIS sequence was available (Figure 2). However, these two species, were not close to C. asianum, thus, can be excluded from the three loci analysis. Moreover, the two loci analysis (data not shown) confirm that they were distinct from C. asianum. There were a total of 1255 positions in the final dataset of the combined three loci. The tree with the highest log likelihood (-2531.80) is shown in Figure 2, the tree is drawn to scale, with branch lengths measured in the number of substitutions per site, and the percentage of trees in which the associated taxa clustered together is shown next to the branches (bootstraps). 


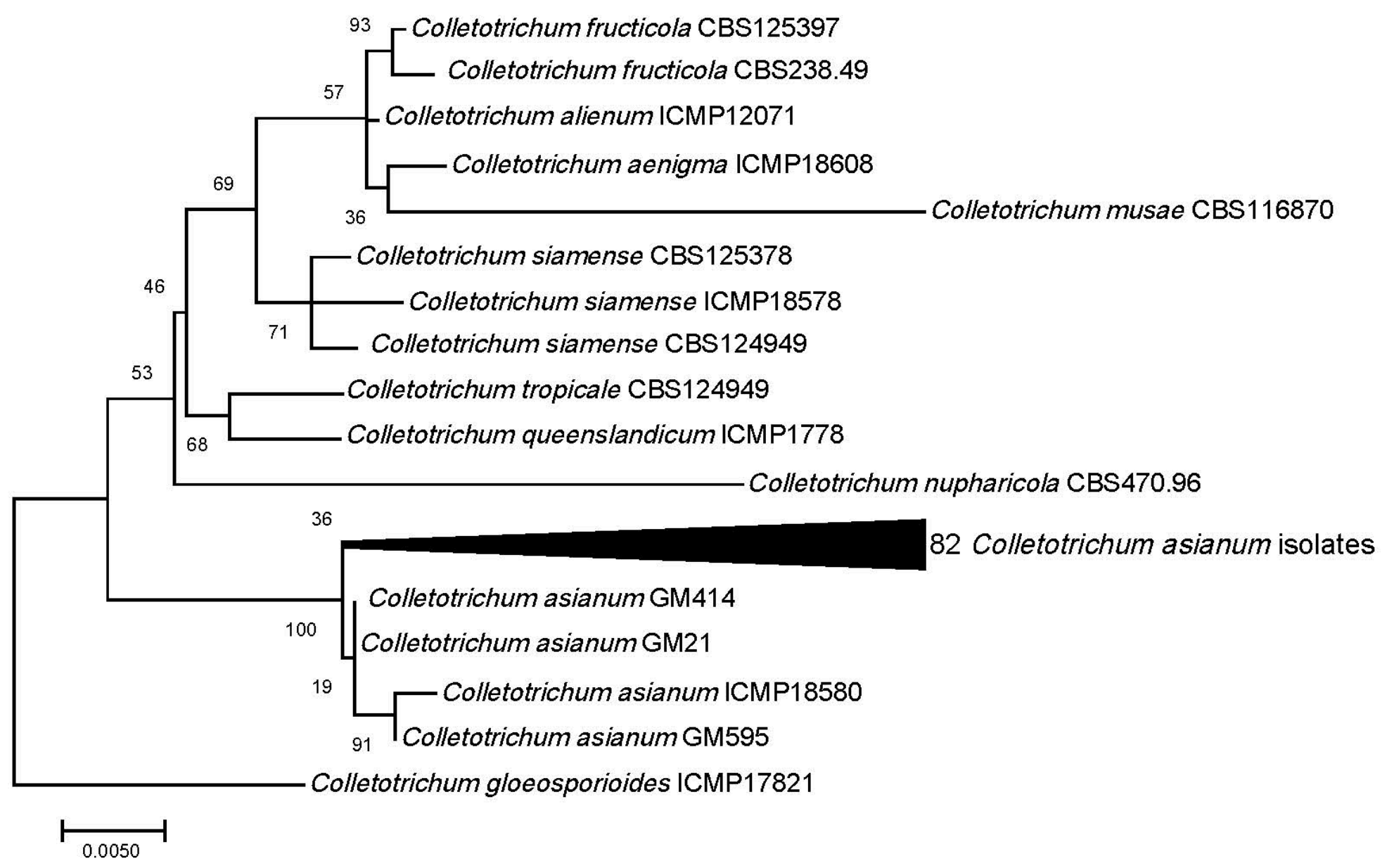

Figure 2. Three loci (ITS, TUB, HIS) phylogeny of the 82 C. asianum isolated from Mangifera indica in the Brazilian Mango Germplasm Collection at the Sementeira Farm, Universidade Federal de Viçosa in southeastern Brazil. 


\subsection{Susceptibility of Mango Cultivars}

The amount of anthracnose leaf infection varied among accessions during the crop season. Due to the high number of detected cultivars, the data showed a continuous gradation in the pathogen susceptibility ranging from high sensitivity to strong tolerance. In other words, the anthracnose susceptibility ranged from mango cultivars with very few symptomatic leaves to cultivars with all infected leaves. Since Colletotrichum is also able to induce leaf anthracnose infections very variable in the number of spots, size and placement on leaf blade (Figure 1A-E) an empirical method has been set up for grouping mango accessions taking simultaneously into account DI and SS value (Table 1).

Table 1. Phenotype groups of mango susceptibility according to anthracnose disease incidence (DI) and severity (SS).

\begin{tabular}{|c|c|}
\hline Phenotype & Group range description \\
\hline Resistant & $=$ no anthracnose symptoms ( $0 \%$ DI and SS on plant canopy) \\
\hline Strongly tolerant & $=$ DI up to $9.0 \%$ or SS less than class 1.5 (from 1 to 2.0 class) \\
\hline Tolerant & $=$ DI more than $9.0 \%$ (up to $19 \%$ ) or SS more than class 2.0 (from 1.5 to 3.0 class) \\
\hline Moderately tolerant & $=$ DI more than $19.0 \%$ (up to $40 \%$ ) or SS more than class 3.0 (from 1.75 to 3.5 class) \\
\hline Moderately sensitive & $=$ DI more than $40 \%$ (up to $55 \%$ ) or SS more than class 3.5 (from 2.75 to 4.25 class) \\
\hline Sensitive & $=$ DI more than $55 \%$ (up to $85 \%$ ) or SS more than class 4.25 (from 3.5 to 5.75 class) \\
\hline Highly sensitive & $=$ DI more than $85 \%$ (up to $100 \%$ ) or SS more than class 5.75 (from 4.0 to 7.0 class) \\
\hline
\end{tabular}

Disease incidence was calculated on the basis of the percentage of symptomatic leaves on each plant, whereas SS always referred to an empirical 0-to-12 rating scale set-up properly for the evaluation of leaf anthracnose amount as well explained in the materials and methods section (Figure 3). 


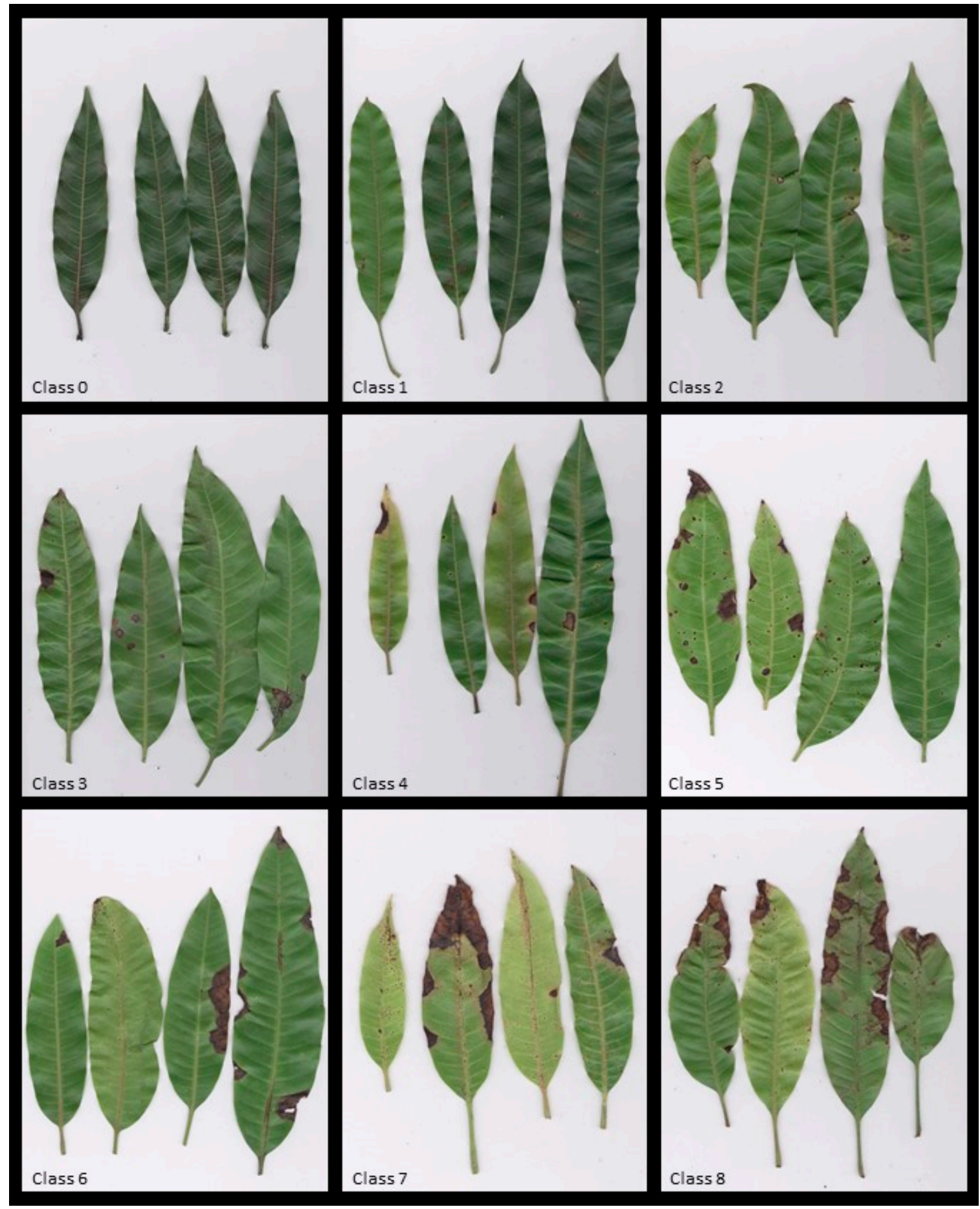

Figure 3. Nine (0-to-8) of total (13) disease classes detected within empirical scale adopted to evaluate severity of leaf infections caused by C. asianum during susceptibility mango evaluation at the Sementeira Farm, Universidade Federal de Viçosa (A-E).

Subsequently, the average DI and SS data relative to each phenotype group are reported in Table 2. 
Table 2. Mango cultivars grouped for susceptibility phenotype to anthracnose infections and relative DI and severity (SS).

\begin{tabular}{|c|c|c|c|}
\hline Phenotype & Cultivar ${ }^{a}$ & DI $(\%)^{b}$ & SS (0-to-12 scale) ${ }^{b}$ \\
\hline Resistant & No cultivar & - & - \\
\hline Strongly tolerant & $\begin{array}{c}\text { Lita, Natalina, Ourinho, Mallika, Nam Dok Mai, Alfa, Heidi, Manilla, Ouroporanga, } \\
\text { Winter, Nandoca Arroxeada }\end{array}$ & $5.25 \pm 0.69$ & $1.59 \pm 0.14$ \\
\hline Tolerant & $\begin{array}{c}\text { Sensação, Coração De Boi Escalope, Carlotinha, Iac 122, Kent, Irwin, Juazeiro, Roxa, } \\
\text { Espada Valentin, Surpresa, Parvin }\end{array}$ & $12.92 \pm 0.84$ & $2.11 \pm 0.12$ \\
\hline Moderately tolerant & $\begin{array}{l}\text { Pequi, Itamaracá, Carabao, Umbigo, Imbú, Coração De Boi Barbosa, Espada Ouro, } \\
\text { Votupá, Santo Antônio, Tommy Atkins, Ômega, Iac 136, Apple, Coquinho, Tinfan, Haden } \\
\text { 2h, Haden, Ias Haden, Extrema, Neldica, Rosa Vila, Mamão, Fafà } \\
\text { Lira, Espada, Carlota, Batista, Iac } 105 \text { Palmeiras, Mastruz, De Cheiro, Ubá Juste, Van }\end{array}$ & $27.93 \pm 1.32$ & $2.73 \pm 0.10$ \\
\hline Moderately sensitive & $\begin{array}{c}\text { Dike, Kensington Pride, Mabrooca, Pope, Castro, Sabina Fronteira, Bourbon Do Cláudio, } \\
\text { Bourbon, Bourbon Vermelha, Espada Stahl }\end{array}$ & $45.46 \pm 1.75$ & $3.54 \pm 0.10$ \\
\hline Sensitive & $\begin{array}{c}\text { Dura, Fiapo, Imperial, Governadora, Torrinha, Coração De Boi, Gioana, Rosa Astolfo } \\
\text { Dutra, Pingo D'ouro, Vovó, Sabina Léo, Espada Itápolis, Keitt }\end{array}$ & $64.81 \pm 2.37$ & $4.58 \pm 0.16$ \\
\hline Highly sensitive & $\begin{array}{c}\text { Ubá, Correio, Aroeira, Rosa, Sapatinho, Amarelinha Da Sementeira, Palmer, Quinzenga, } \\
\text { Espada Perdões, Roxinha Da Sementeira }\end{array}$ & $96.63 \pm 2.08$ & $5.79 \pm 0.29$ \\
\hline
\end{tabular}

a An amount of 86 mango cultivars was monitored in the Brazilian Mango Germplasm Collection at the Sementeira Farm, Universidade Federal de Viçosa. ${ }^{\mathrm{b}}$ Data are means of disease parameters \pm standard error of the mean (SEM) of all mango cultivars included in each phenotype group. 
No resistant cultivars were present in this germplasm collection. Among them, 11 were classified as strongly tolerant since DI was always less than $9 \%$ and SS index ranging from 1 to 2 . The same number (11) were categorized as tolerant with DI ranging from $9.5 \%$ to $18.75 \%$ and mean SS higher than 2 (Table 2). On the other hand, 10 and 13 accessions, intercepting mean DI values of about $97 \%$ and $65 \%$, and SS of about 5.8 and 4.6 , were classified as highly sensitive and sensitive, respectively. The remaining 41 cultivars were classified as moderately tolerant (23) and moderately sensitive (18) with intermediate DI and SS values as it is reported in Table 2.

However, the frequency distribution of mango cultivars within the established categories is not perfectly balanced (roughly normal distribution). As expected, it shows a prevalence of intermediate susceptibility categories (moderately tolerant and moderately sensitive) with a cumulative value of $47.7 \%$ on the total of examined germplasm whereas the distribution tails intercept $26.7 \%$ of susceptible (sensitive and highly sensitive) and $25.6 \%$ of resistant (tolerant and highly tolerant) accessions, respectively (Figure 4).

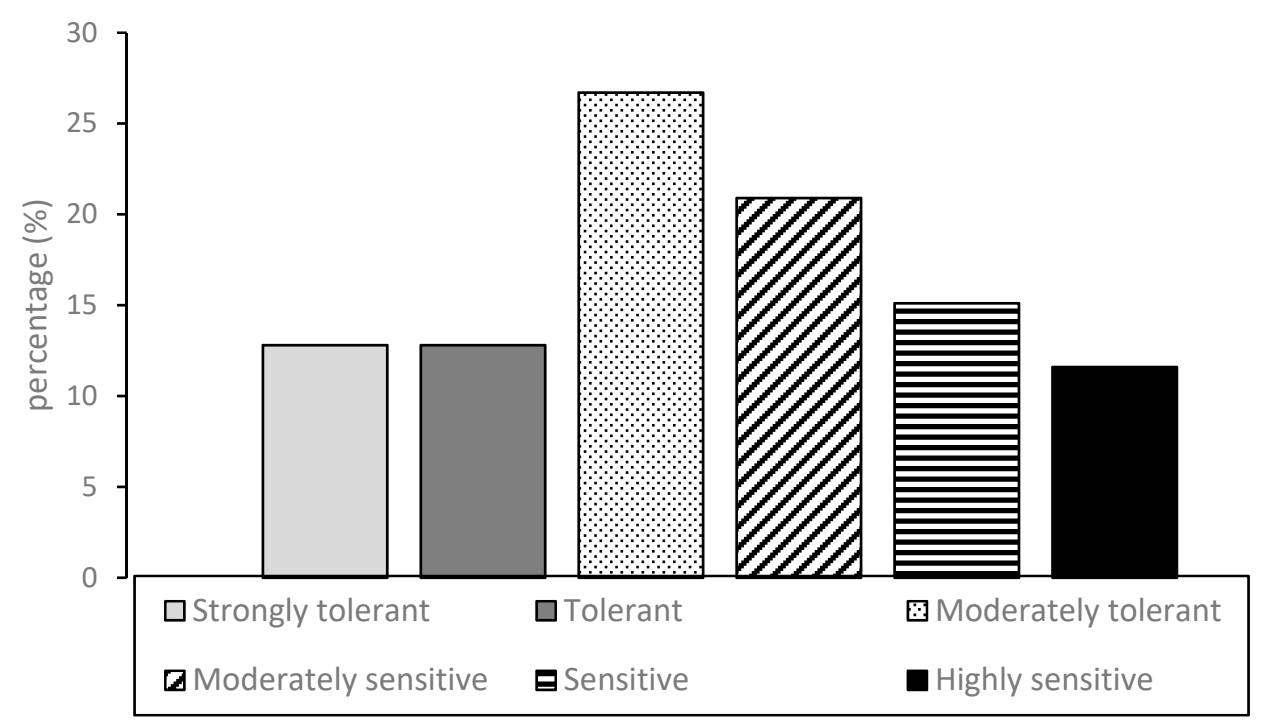

Figure 4. Percentage distribution of mango cultivars having a different sensitivity/tolerance response to anthracnose leaf infections caused by C. asianum in the Brazilian Mango Germplasm Collection at the Sementeira Farm, Universidade Federal de Viçosa.

Within strongly tolerant germplasm group, Mallika, Manilla and Nam Dok Mai showed significantly lower DI values if compared with Alfa and Ouroporanga cultivars whereas the SS values were significantly lower on Mallika, Ourinho and Lita cultivars if compared with those observed on Winter Nandoca Arroxeada, Ouroporanga, Nam Dok Mai and Natalina. Comprehensively, Mallika exhibited the lowest susceptibility to leaf anthracnose infections incited by C. asianum while Ouroporanga displayed the highest disease amount values (Figure 5). 


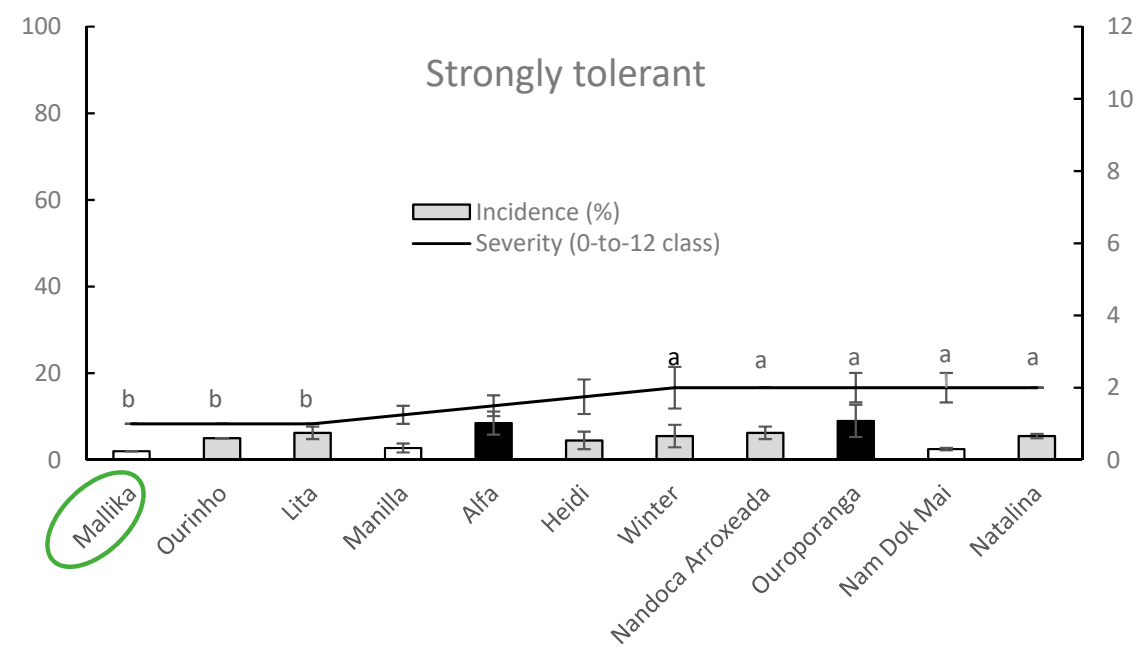

Figure 5. Column-line graphs on two axes comparing anthracnose DI and SS caused by C. asianum within strongly tolerant mango cultivars. Average DI and SS data from three monitoring times $( \pm$ SE: standard error) are the means of four replicates (plants) obtained from disease incidence on each canopy and 16 leaves per plant, respectively. Arcsine transformation was used on percentage data prior to analysis, whereas untransformed data are presented. Black and white columns are significantly different among them according to Fisher's least significant difference test at $\alpha=0.05$ while grey color denotes intermediate behavior (not significant). Differences among severity data on-line among cultivars (points followed by different letters) were analyzed with Kruskal-Wallis one-way analysis of variance by ranks followed by all pairwise multiple comparisons with Mann-Whitney test. The missing letters denote non-significant differences from all remaining severity values.

Irwin cultivar showed a DI value significantly lower than one observed on Iac122 cultivar within tolerant mango germplasm group whereas the remaining cultivars showed an intermediate anthracnose incidence. Regarding the mean SS data, Sensação, Coração de Boi Escalope, and Iac122 significantly differed (lower data) from Juazeiro and Roxa cultivars whereas Kent (among the most well-known cultivars), Irwin (with a low disease incidence) and remaining tolerant cultivars had intermediate leaf anthracnose severities (data not significant) (Figure 6).

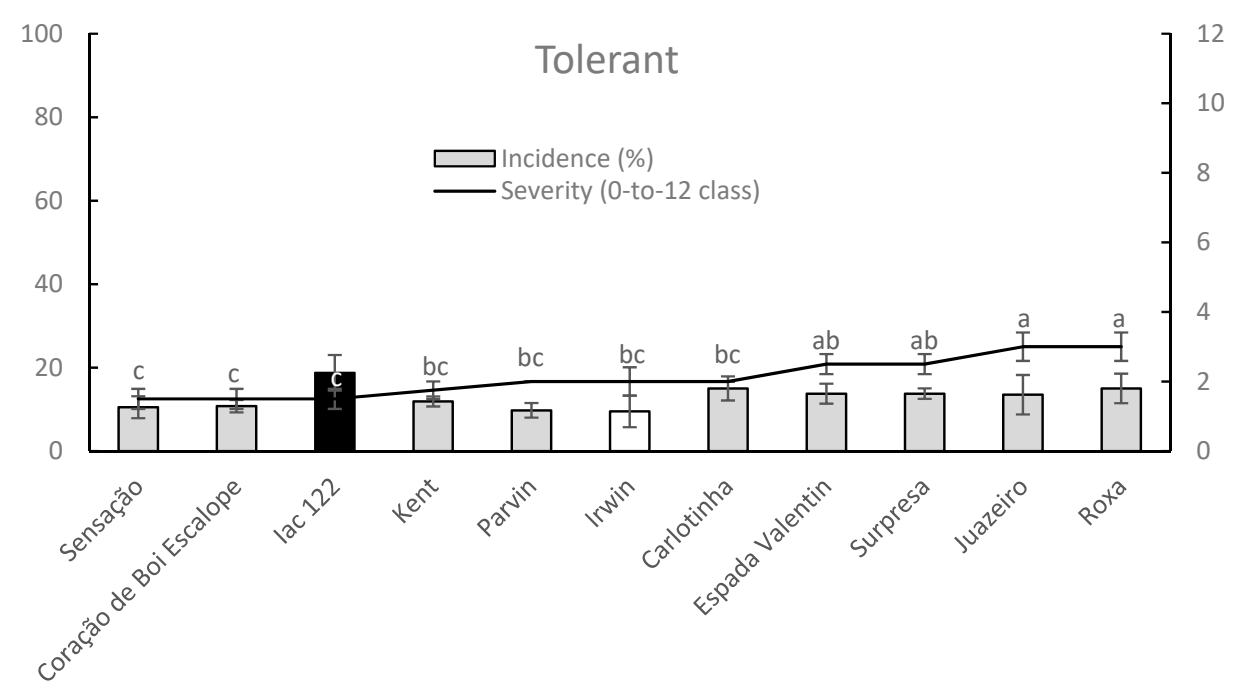

Figure 6. Column-line graphs on two axes comparing anthracnose DI and SS caused by C. asianum within tolerant mango cultivars. Data ( \pm SE values) were collected and analyzed as above mentioned for the previous figure. Grey color of columns clearly shows the lack of significant differences according to both parametric and nonparametric approaches. 
Since a great variability was investigated on mango orchard for DI and SS parameters within moderately tolerant and moderately sensitive groups respectively it was very difficult to discriminate significant differences among examined cultivars within these groups, respectively (Figures 7 and 8).

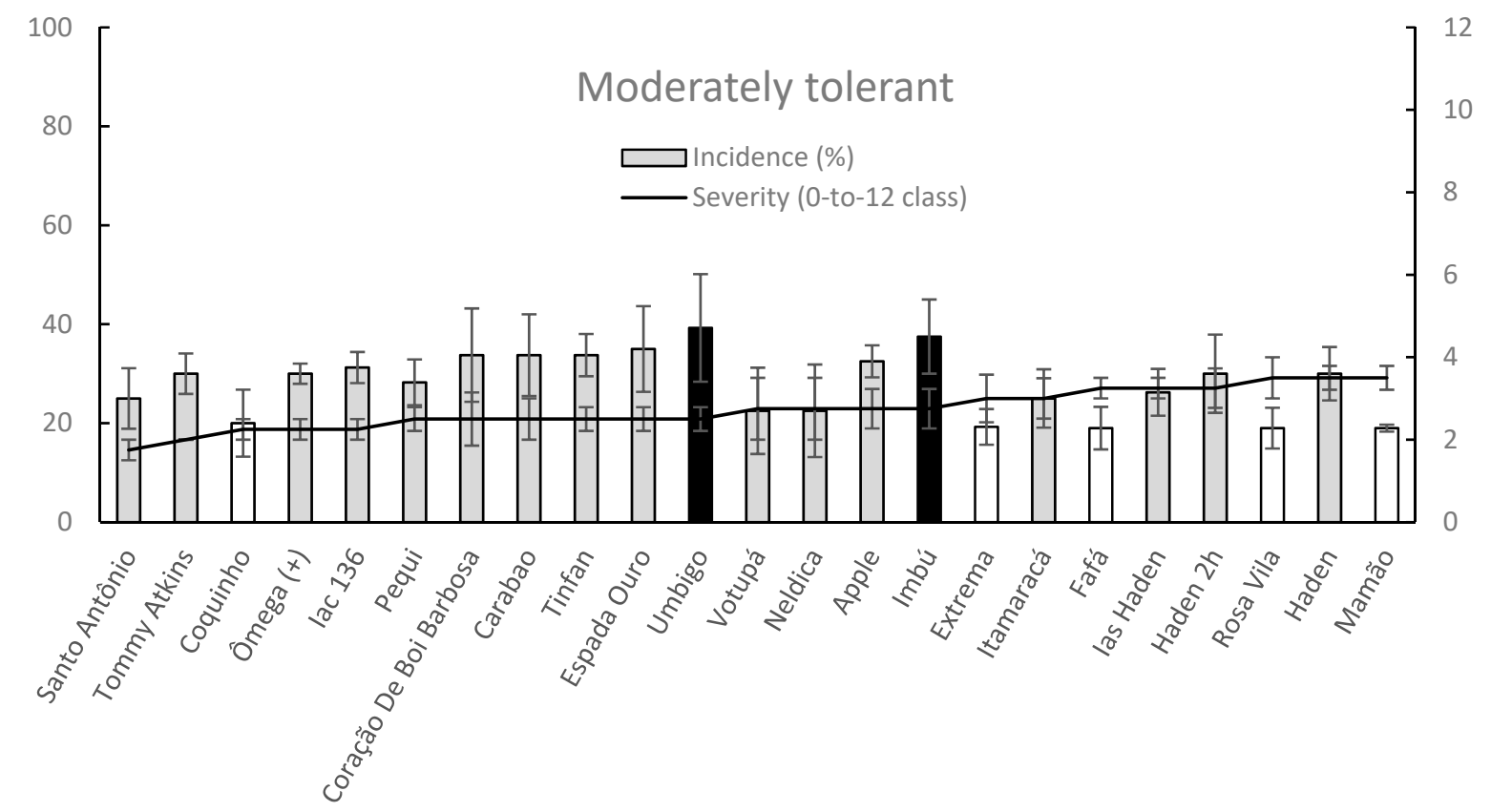

Figure 7. Column-line graphs on two axes comparing anthracnose incidence and severity caused by $C$. asianum within moderately tolerant mango cultivars. Data ( \pm SE values) were collected and analyzed as above done for previous figures. Grey colors of columns, as well as the absence of letters above the points of line, clearly show the lack of significant differences according to both parametric and nonparametric approaches.

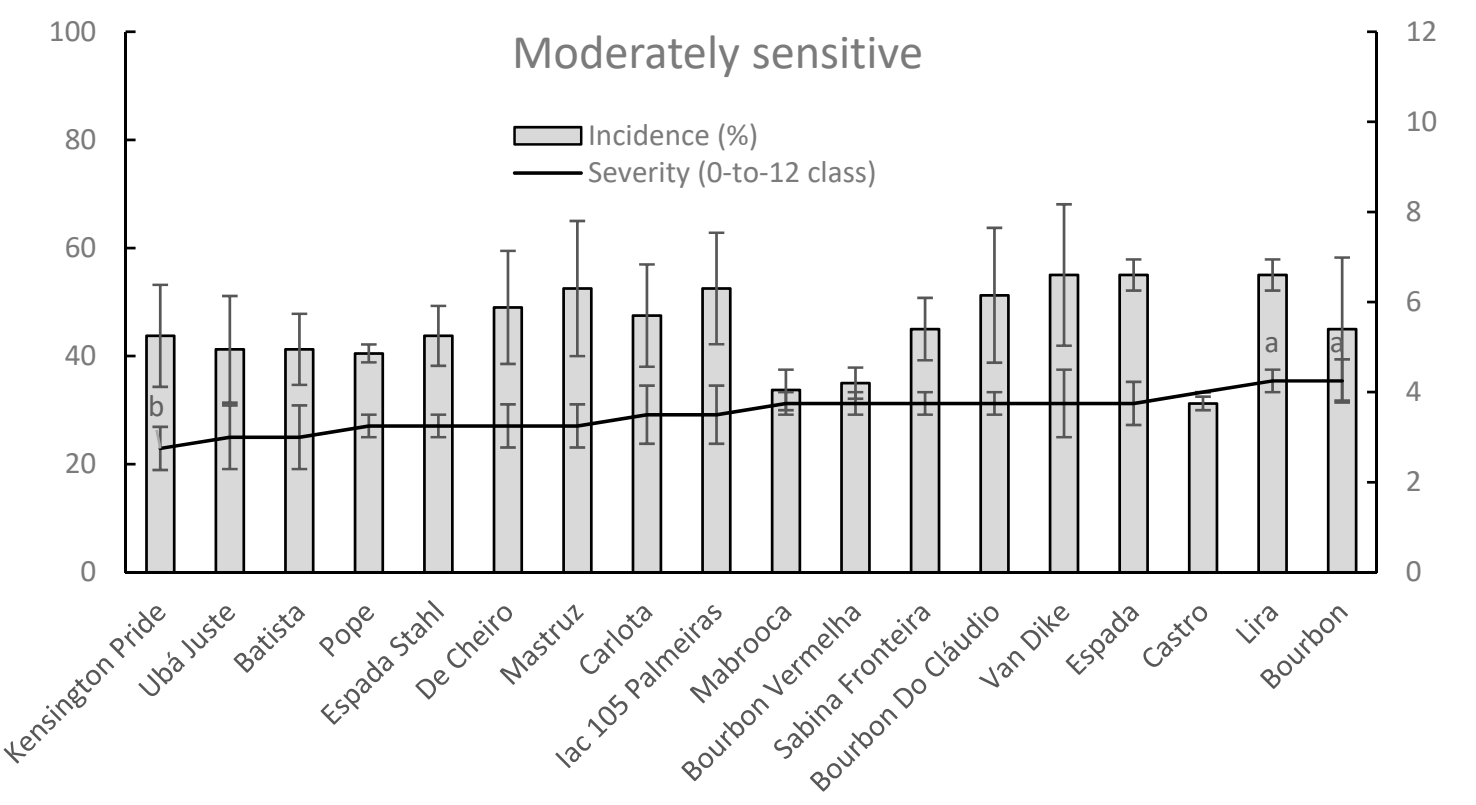

Figure 8. Column-line graphs on two axes comparing anthracnose incidence and severity caused by C. asianum within moderately sensitive mango cultivars. Data ( \pm SE values) were collected and analyzed as above done for previous figures. Grey colors of columns, as well as the absence of letters above points of the line, clearly show the lack of significant differences according to both parametric and nonparametric approaches. 
In the moderately tolerant group, only Couquinho, Extrema, Fafá, Rosa Vila and Mamão showed DI values significantly lower than those of Umbigo and Imbú whereas the remaining ones, including the well-known mango cultivars Tommy Atkins and Haden (Figure 7).

Otherwise, within the moderately sensitive group the only significant differences amongst cultivars were detected for SS parameter between well-known Kensington Pride (lower values) and Lira and Bourbon (higher values) (Figure 8).

Within sensitive mango germplasm group (Figure 9), five cultivars (Gioana, Coração de Boi, Vovó, Fiapo and Dura) exhibited a significant lower anthracnose diffusion (DI) data when compared with Espada Itápolis cultivar while the remaining cultivars did not significantly differ among all tested cultivars.

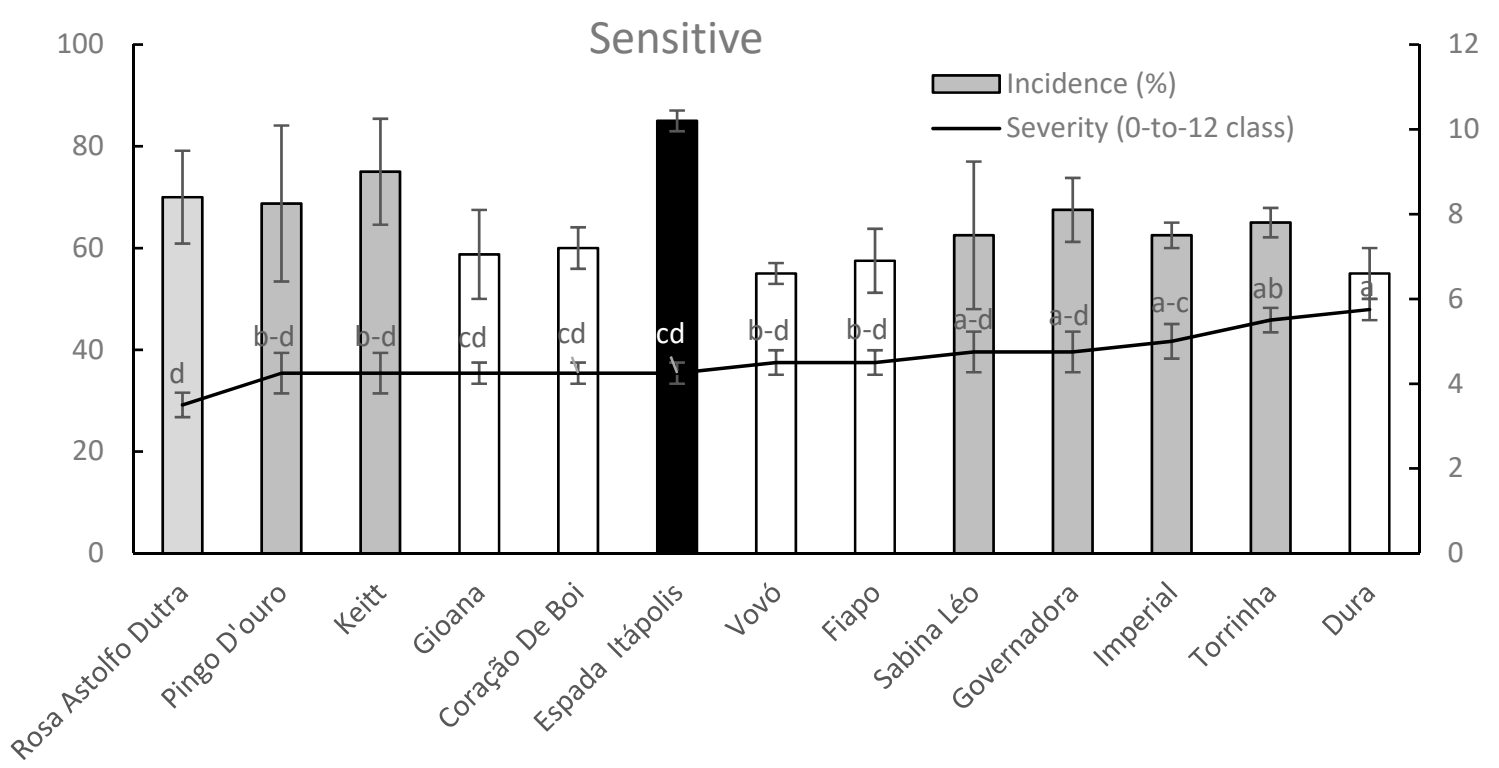

Figure 9. Column-line graphs on two axes comparing anthracnose incidence and severity caused by $C$. asianum within sensitive mango cultivars. Data ( \pm SE values) were collected and analyzed as above done for previous figures. Grey colors of columns, as well as the absence of letters above points of the line, clearly shows the lack of significant differences according to both parametric and nonparametric approaches.

On the other hand, Rosa Astolfo Dutra exhibited a mean SS value significantly lower than those of Imperial, Torrinha and Dura whereas intermediate anthracnose sensitivity values were recorded for remaining cultivars including the well-known cultivar Keitt (Figure 9).

In the highly sensitive germplasm group (Figure 10), mango cultivars Sapatinho and Rosa showed anthracnose incidence values significantly lower $(\alpha=0.05)$ than the remaining cultivars except for the Espada Perdões (grey color). On the other hand, this latter cultivar exhibited an SS value significantly lower than those of all cultivars of the group except for Roxinha da Sementeira. 


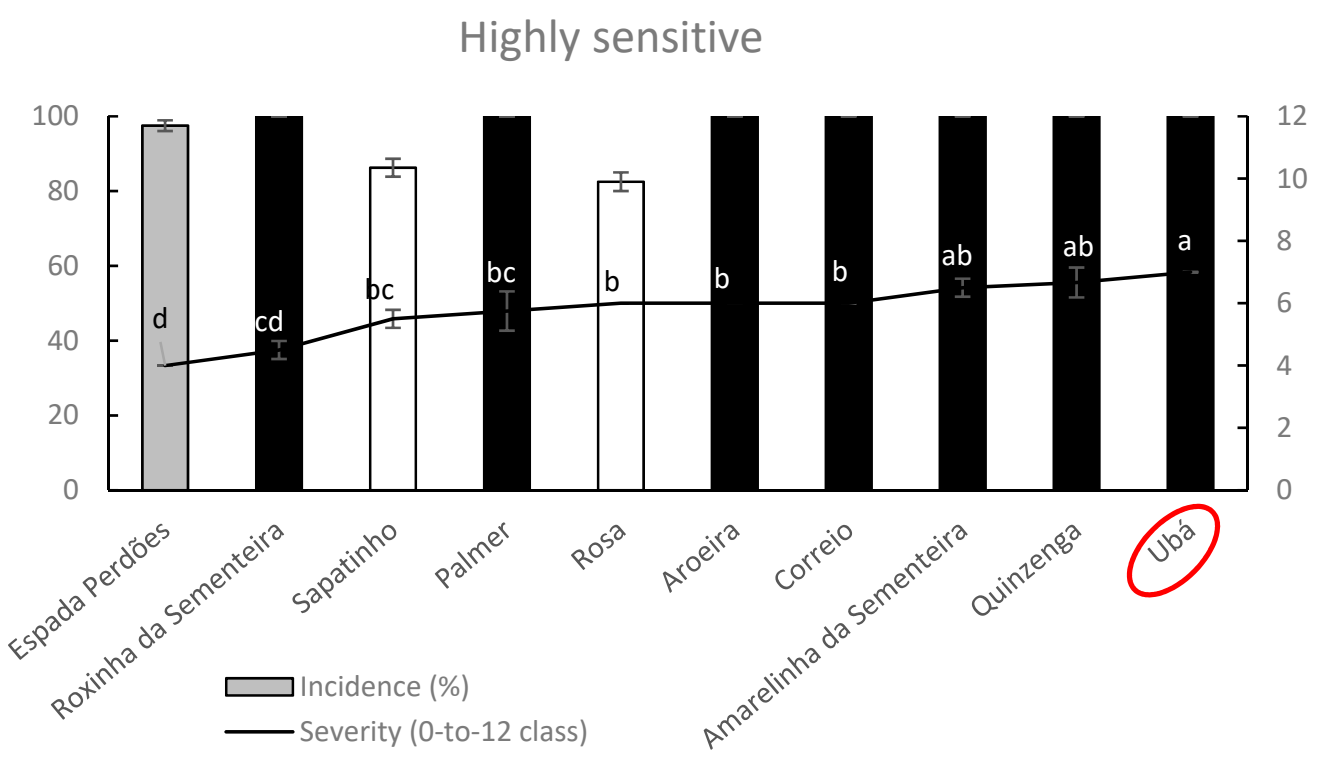

Figure 10. Column-line graphs on two axes comparing anthracnose incidence and severity caused by C. asianum within highly sensitive mango cultivars. Data ( \pm SE values) were collected and analyzed as above done for previous figures. Grey colors of columns, as well as the absence of letters above points of the line, clearly shows the lack of significant differences according to both parametric and nonparametric approaches.

Overall, cultivar Ubá followed by Quinzenga and Amarelinha da Sementeira resulted in higher sensitivity to anthracnose infections caused by C. asianum. Other well-known mango cultivar Palmer fell in this highly sensitive germplasm group (Figure 10).

\section{Discussion}

In this study, we present the first data on the evaluation of susceptibility to anthracnose leaf infections in an important mango germplasm collection of southeastern Brazil. The paper also represents the first report describing Colletotrichum species responsible for the widespread occurrence of anthracnose infections on mango orchards in the Minas Gerais region. C. asianum, C. dianesei, C. fructicola, C. karstii, C. tropicale, C. cliviae and C. endomangiferae have been previously reported as responsible for mango anthracnose in Brazil [21,24,34], whereas, in the present study both morphological and phylogenetic analyses revealed that solely C. asianum was found associated with disease infections in field. In particular, the three genes phylogeny clearly grouped the 82 representative strains within the C. asianum branch with high bootstrap support $(100 \%)$. This finding is not surprising since this latter species is worldwide reported as the most prevalent and virulent from the main mango production areas of Brazil and around the world [24,28,30-32,34,35]. However, the presence of a single species as a causal agent of anthracnose has facilitated the disease susceptibility assessment when compared to other phytosanitary conditions where more Colletotrichum species are involved in disease infections. Although the disease evaluation was done on mango plant canopies (leaves), these data are valuable since the fungus is polycyclic and the role exerted by leaf infections in enhancing disease amount and duration of epidemics is crucial [36]. This is more evident in mango since this crop has at least three vegetative periods, depending on adopted cultivar [37,38]. However, it well-known as early leaf infection assessment can represent an efficient predictive method to reduce fruit losses in the orchard [39-41] as it was demonstrated for mango germplasm screening to anthracnose where leaf and fruit infections coexisted in orchard [32,42-44]. Although cultivar response to anthracnose attacks was very variable there is a clear predominance of cultivars with intermediate tolerance/susceptibility degrees, i.e., with moderate tolerance and moderate susceptibility toward anthracnose. As a consequence, a clear separation of susceptibility behavior within these groups was not always possible amongst these mango 
accessions as it happens for Tommy Atkins and Haden, and Kensington Pride that were assigned to these groups. Currently, resistance has not been used as consistent means for control of mango anthracnose. This is partially due to the variable disease response of cultivars to the anthracnose from one location to another. In this regard, the literature on host resistance of mango germplasm reported worldwide are quite controversial [42,45-51]. Besides to above reason, this discrepancy is also due to the fact that local susceptibility evaluations were always referred to C. gloeosporioides s. lat. without considering accurate Colletotrichum species involved in anthracnose infections. It is also interesting note that none of the accessions examined here were resistant and none of the commercial cultivars cannot generally provide under environment humid conditions adequate qualitative and quantitative yields without scheduled fungicide spray applications [5]. To sum up, Mallika revealed in our phytosanitary conditions to be the most tolerant accession to C. asianum attacks, while Kent and Irwin were categorized as tolerant accessions. On the other hand, the well-known cultivar Ubá for this Brazilian region revealed to be the most sensitive to fungal infections of C. asianum. The well-known cultivar Keitt revealed to be sensitive to anthracnose attacks.

Although these findings should be confirmed under different conditions, the paper gained for the first time a preliminary insight about the susceptibility of several mango species to C. asianum. The establishment of susceptibility to $C$. asianum against which coming changes can be measured is a crucial and starting point for evaluating the tolerance of local, commercial and well-known mango germplasm under specific agronomic and phytosanitary conditions. For future studies, the methodology described here should also be used to evaluate the cultivar response to other aerial fungal pathogens affecting canopy of mango. Although host resistance alone is not resolutive, it can be considered a sustainable mean since pathologists and breeders can use it both to implement IPM strategies for mango anthracnose caused by C. asianum and to reduce number fungicide treatments.

\section{Materials and Methods}

\subsection{Plant Material and Orchard}

A wide disease survey was performed in 2014 using the most important mango germplasm collection located in Southeastern Brazil (Minas Gerais, MG region). The entire collection constitutes about two hundred accessions of mango cultivars from different countries and areas of origin. The accessions are conserved as a live collection at the Sementeira Farm located in a wide orchard subdivided into several areas. The entire collection (Banco De Germoplasma De Mangueiras, Fazenda Experimental da Sementeira-BGM-FES), belonging to the Universidade Federal de Viçosa in the municipality of Visconde do Rio Branco, MG (21 $00^{\prime} 37^{\prime \prime} \mathrm{S}, 42^{\circ} 50^{\prime} 26^{\prime \prime} \mathrm{W}$; $352 \mathrm{~m}$ altitude), had in the recent past growing seasons a history of severe anthracnose infections. For most cultivars tested in this paper, the degree susceptibility (with particular reference to strongly tolerant and highly sensitive cultivars) versus anthracnose was very similar to one presented here.

\subsection{Isolations and Morphological Characterization}

Isolations were made from symptoms of infected leaves of all cultivars. Small sections from the edge of lesions were disinfested in $1 \% \mathrm{NaOCl}(1 \mathrm{~min})$, rinsed in sterile distilled water (SDW) and placed onto potato dextrose agar (PDA, Oxoid, Basingstoke, UK) with streptomycin sulfate $(100 \mu \mathrm{g} / \mathrm{mL})$ and incubated at $25 \pm 1{ }^{\circ} \mathrm{C}$ with a 12-h photoperiod. At least two single-spore isolates were obtained from each mango sample. Morphological characterization of isolates was performed by using single conidial cultures prepared on PDA. In detail, monoconidial cultures of Colletotrichum species were incubated at $25{ }^{\circ} \mathrm{C}$ in the dark on PDA. Conidia were examined after 10 days of incubation. Conidial shape and color were determined by mounting fungal structures in clear lactic acid. Measurements of 50 conidia for each representative isolate were determined at 400 and 1000× using an optical microscope with interference contrast illumination. The mean measurements of conidia were calculated. Colony characteristics were determined after seven-day period growth at $25^{\circ} \mathrm{C}$ on PDA. 


\subsection{DNA Isolation, PCR and Phylogeny}

The species-level identification was obtained by DNA sequencing and phylogenetic analyses of $\beta$-tubulin (TUB2), histone H3 (HIS3) and nuclear ribosomal internal transcribed spacer (ITS) region gene sequences of the 82 strains (almost one representative isolate from each examined cultivar) tested in this study. Isolates were grown in potato dextrose broth (PDB, Sigma-Aldrich, Saint Louis, MO, USA) incubated at $25{ }^{\circ} \mathrm{C}$ in the dark, under shaking, for 4-6 days. Mycelial mats were collected, dried with sterile filter paper, frozen in liquid nitrogen and ground to a fine powder. Genomic DNA extraction was performed using Wizard Magnetic DNA Purification System for Food kit (Promega, Madison, WI, USA) according to the manufacturer's protocol. The quality of genomic DNA was determined by agarose gel electrophoresis and quantified through a Nanodrop ND-1000 Spectrophotometer (Thermo Fisher Scientific, Wilmington, DE, USA). Part of the $\beta$-tubulin gene was amplified using primers T1 [52]) and Bt2b [53]. ITS1 and ITS4 primers [54] were used to amplify part of the Internal Transcribed Spacer (ITS) region of the rRNA (the $3^{\prime}$ end of the $18 \mathrm{~S}$ rRNA gene, the internal spacers, the $5.8 \mathrm{~S}$ rRNA gene and a part of the $5^{\prime}$ end of the 28S rRNA) gene. For the histone H3 region, CYLH3F and CYLH3R primers [55] were used. PCR amplifications were carried out with HotMaster Taq DNA Polymerase, nucleotides and buffer supplied by 5Prime (PRIME GmbH, Hamburg, Germany). The PCR reaction mixture contains 1x HotMaster Taq Buffer with Mg2+, 200 uM dNTP Mix, 1 U HotMaster Taq DNA Polymerase, 0,1uM of each primer and 50-100 ng of template DNA. Sequencing was performed using an AB 3730 DNA analyzer (Applied Biosystems, Foster City, CA, USA). BigDye Terminator cycle sequencing kit (version 3.1; Applied Biosystems) was used following the manufacturer's manual on both strands by the same primers. The basic local alignment search tool (BLAST) in GenBank (www.ncbi.nlm.nih.gov/blast) was queried after aligning, editing and trimming the sequences by Geneious R10 (Biomatters Ltd.). Sequences of the three loci (TUB2, HIS3, ITS) of reference type strains belonging to the musae clade of the C. gloeosporioides species complex, were retrieved from GenBank. The multi-locus alignment was performed using MEGA-X [56] software with manual adjustment. The phylogenetic analyses were conducted on the combined multilocus alignment of two (ITS, TUB2) or three loci. Tamura [57] and Tamura-Nei [58] were the best evolution model suggested for the analysis of the two and three loci alignment, respectively. Phylogenetic analyses were inferred by using the maximum likelihood method with five gamma categories and 1000 bootstrap replications.

\subsection{Monitoring and Field Sampling}

During the crop season of 2014, 86 mango cultivars were evaluated in three different monitoring times (from April to May with an interval of 25 days) at the same locations for their susceptibility to leaf anthracnose infections under natural anthracnose disease pressure. Since low disease level, data on fruit infections collected during other months are not detected. Tested mango cultivars located in four distinct areas of germplasm collection were scored for their susceptibility/tolerance to leaf anthracnose infection evaluating four plants (four replicates) by assessment of disease incidence (DI) and symptoms severity (SS) parameters. The former (DI-qualitative parameter) was always referred to the assessment of average percentage of symptomatic leaves on entire canopy of each plant whereas SS (quantitative parameter) was accounted on 16 leaves (for each replicate of each cultivar, four leaves per each of four sub-replicates) adopting an empirical 0-to-12 rating scale set up for evaluation of leaf anthracnose amount. This empirical scale takes into account the mean percentage of infected surface where $0=$ no symptoms; $1=$ up to $0.5 \%$ of infected leaf surface; $2=0.6$ to $1 \% ; 3=1.1$ to $2 \% ; 4=2.1$ to $3 \% ; 5=3.1$ to $4 \% ; 6=4.1$ to $6 \% ; 7=6.1$ to $10 \% ; 8=10.1$ to $25 \% ; 9=25.1$ to $40 \% ; 10=40.1$ to $60 \%$; $11=60.1$ to $75 \% ; 12=$ more than $75 \%$ of infected leaf surface. To measure the infected leaf area, mango leaves were well extended and the relative images were captured using a scanner (HP Scanjet G2710) 
(Figure 3). From the images, the infected leaf area was measured by ImageJ [59]. Definitively, the average leaf anthracnose severity was always calculated by the following formula:

$$
S S=\frac{\sum_{i=0}^{12}(\mathrm{C} i \times \mathrm{n})}{\mathrm{N}},
$$

where SS is the average index of severity symptoms, $\mathrm{C} i$ each class detected, $\mathrm{n}$ the number of leaves in each class, $i$ (0-to-12) the numerical values of classes, $\mathrm{N}$ the total number of leaves examined. The definitive DI and SS data (as average resulting from three evaluating periods since monitoring was carried out in triplicate) was always confirmed by an adequate number of isolation attempts performed in the laboratory (at least from 10 to 20 attempts for each leaf sample with little clear symptoms) from symptomatic mango samples (Figure $1 \mathrm{~F}$ ) and consequentially adjusted on the basis of obtained recovery data. Finally, the cultivars were classified into seven categories (resistant, strongly tolerant, tolerant, moderately tolerant, moderately susceptible, susceptible and highly susceptible) according to combined DI and SS definitive data.

\subsection{Statistical Analysis}

STATISTICA package software (version 10; Statsoft Inc., Tulsa, OK, USA) was used for statistical analyses according to parametric or nonparametric approaches for randomized complete block design (RCBD) with the different cultivars having four replicates. In the posthoc analysis the mean separation was conducted on DI data using post-hoc Fisher's least significant difference test at $\alpha=0.05$. Prior to analysis, percentage values were transformed as arcsine square root $\left(\sin ^{-1}\right.$ square root $\left.\mathrm{x}\right)$ to improve homogeneity of variances [60], whereas untransformed arithmetic means of DI are shown in the figures. Because an ordinal scale (0-to-12 empirical classes) was adopted for assessment of anthracnose severity (Figure 3), rank sums of SS data were analyzed according to a nonparametric approach, i.e., Kruskal-Wallis one-way analysis ( $\chi^{2}$ value and associated $p$ level $<0.05$ indicate the significance) for experiment wise significance followed by all possible pairwise comparisons using the Mann-Whitney test $(z>2.58 ; p<0.01)[61]$.

Author Contributions: Conceptualization, methodology, software, validation, formal analysis, investigation, data curation, writing - original draft preparation, writing - review and editing, visualization, supervision A.V.; supervision, project administration, funding acquisition, resources A.C.A. and G.P. (Giancarlo Polizzi).; resources, D.L.d.S.; methodology, software, formal analysis, G.P. (Giancarlo Perrone) and D.M. All authors have read and agreed to the published version of the manuscript.

Funding: This research was funded by the Research Project 2016-2018 “Emergent Pests and Pathogens and Relative Sustainable Management Strategies" financed by the University of Catania - 5A722192112.

Acknowledgments: The first and corresponding author is extremely grateful to A.C. Alfenas and D.L. De Siqueira for the hospitality received in BGM and in laboratories of Universidade Federal de Viçosa.

Conflicts of Interest: The authors declare no conflict of interest. The funder had no role in the design, collection of data, and its interpretation; in the writing of the manuscript; and in the decision to publish the manuscript.

\section{References}

1. Altendorf, S. Major Tropical Fruits Market Review; FAO: Rome, Italy, 2017; p. 10. Available online: http: //www.fao.org (accessed on 2 September 2019).

2. Mitra, S.K. Mango production in the world: Present situation and future prospect. Acta Hortic. 2016, 1111, 287-296. [CrossRef]

3. Pott, I.; Marx, M.; Neidhart, S.; Muhlbauer, W.; Carle, R. Quantitative determination of b-carotene stereoisomers in fresh, dried, and solar dried mangoes (Mangifera indica L.). J. Agric. Food Chem. 2003, 51, 4527-4531. [CrossRef]

4. Nadeem, M.; Imran, M.; Khalique, A. Promising features of mango (Mangifera indica L.) kernel oil: A review. J. Food Sci. Technol. 2016, 53, 2185-2195. [CrossRef] 
5. Arauz, L.F. Mango anthracnose: Economic impact and current options for integrated management. Plant Dis. 2000, 84, 600-611. [CrossRef]

6. Akem, C.N. Mango anthracnose disease: Present status and future research priorities. Plant Pathol. J. 2006, 5, 266-273.

7. Sutton, B.C. The Coelomycetes: Fungi Imperfecti with Pycnidia, Acerouli and Stromata; Commonwealth Mycological Institute: Kew, UK, 1980; pp. 1-696.

8. Sutton, B.C. The genus Glomerella and its anamorph Colletotrichum. In Colletotrichum: Biology, Pathology and Control; Bailey, J.A., Jeger, M.J., Eds.; CAB International: Wallingford, UK, 1992; pp. 1-26.

9. Cannon, P.F.; Damm, U.; Johnston, P.R.; Weir, B.S. Colletotrichum-current status and future directions. Stud. Mycol. 2012, 73, 181-213. [CrossRef]

10. Damm, U.; Cannon, P.F.; Woudenberg, J.H.C.; Crous, P.W. The Colletotrichum acutatum species complex. Stud. Mycol. 2012, 73, 37-113. [CrossRef]

11. Damm, U.; Cannon, P.F.; Woudenberg, J.H.C.; Johnston, P.R.; Weir, B.S.; Tan, Y.P.; Shivas, R.G.; Crous, P.W. The Colletotrichum boninense species complex. Stud. Mycol. 2012, 73, 1-36. [CrossRef]

12. Damm, U.; Cannon, P.F.; Liu, F.; Barreto, R.W.; Guatimosim, E.; Crous, P.W. The Colletotrichum orbiculare species complex: Important pathogens of field crops and weeds. Fungal Divers. 2013, 61, 29-59. [CrossRef]

13. Damm, U.; O'Connell, R.J.; Groenewald, J.Z.; Crous, P.W. The Colletotrichum destructivum species complex-Hemibiotrophic pathogens of forage and field crops. Stud. Mycol. 2014, 79, 49-84. [CrossRef]

14. Weir, B.S.; Johnston, P.R.; Damm, U. The Colletotrichum gloeosporioides species complex. Stud. Mycol. 2012, 73, 115-180. [CrossRef] [PubMed]

15. Cai, L.; Hyde, K.D.; Taylor, P.W.J.; Weir, B.S.; Waller, J.M.; Abang, M.M.; Zhang, J.Z.; Yang, Y.L.; Phoulivong, S.; Liu, Z.Y.; et al. A polyphasic approach for studying Colletotrichum. Fungal Divers. 2009, 39, 183-204.

16. Hyde, K.D.; Cai, L.; Cannon, P.F.; Crouch, J.A.; Crous, P.W.; Damm, U.; Goodwin, P.H.; Chen, H.; Johnston, P.R.; Jones, E.B.G.; et al. Colletotrichum-names in current use. Fungal Divers. 2009, 39, 147-182.

17. Ismail, A.M.; Cirvilleri, G.; Yaseen, T.; Epifani, F.; Perrone, G.; Polizzi, G. Characterisation of Colletotrichum species causing anthracnose disease of mango in Italy. J. Plant Pathol. 2015, 97, 167-171.

18. Jayawardena, R.S.; Hyde, K.D.; Damm, U.; Cai, L.; Liu, M.; Li, X.H.; Zhang, W.; Zhao, W.S.; Yan, J.Y. Notes on currently accepted species of Colletotrichum. Mycosphere 2016, 7, 1192-1260. [CrossRef]

19. Guarnaccia, V.; Groenewald, J.Z.; Polizzi, G.; Crous, P.W. High species diversity in Colletotrichum associated with citrus diseases in Europe. Persoonia 2017, 39, 32-50. [CrossRef]

20. Sharma, G.; Maymon, M.; Freeman, S. Epidemiology, pathology and identification of Colletotrichum including a novel species associated with avocado (Persea americana) anthracnose in Israel. Sci. Rep. 2017, 7, 15839. [CrossRef]

21. Lima, N.B.; De, A.; Batista, M.V.; De Morais, M.A., Jr.; Barbosa, M.A.G.; Michereff, S.J.; Hyde, K.D.; Câmara, M.P.S. Five Colletotrichum species are responsible for mango anthracnose in northeastern Brazil. Fungal Divers. 2013, 61, 75-88. [CrossRef]

22. Sharma, G.; Kumar, N.; Weir, B.S.; Hyde, K.D.; Shenoy, B.D. The ApMat marker can resolve Colletotrichum species: A case study with Mangifera indica. Fungal Divers. 2013, 61, 117-138. [CrossRef]

23. Udayanga, D.; Manamgoda, D.S.; Liu, X.; Chukeatirote, E.; Hyde, K.D. What are the common anthracnose pathogens of tropical fruits? Fungal Divers. 2013, 61, 165-179. [CrossRef]

24. Vieira, W.A.S.; Michereff, S.J.; de Morais, M.A., Jr.; Hyde, K.D.; Câmara, M.P.S. Endophytic species of Colletotrichum associated with mango in northeastern Brazil. Fungal Divers. 2014, 67, 181-202. [CrossRef]

25. Freeman, S.; Katan, T.; Shabi, E. Characterization of Colletotrichum species responsible for anthracnose diseases of various fruits. Plant Dis. 1998, 82, 596-605. [CrossRef] [PubMed]

26. Ploetz, R.C.; Prakash, O. Foliar, floral and soilborne diseases. In The Mango: Botany, Production and Uses; Litz, R.E., Ed.; CAB International: Oxon, UK, 1997; pp. 281-325.

27. Tarnowski, T. Using Molecular Analysis to Investigate Phylogenetic Relationships in Two Tropical Pathosystems: Witches' Broom of Cacao, Caused by Moniliophthora perniciosa, and Mango Anthracnose, Caused by Colletotrichum spp. Ph.D. Thesis, University of Florida, Gainesville, FL, USA, 2009.

28. Sharma, G.; Gryzenhout, M.; Hyde, K.D.; Pinnaka, A.K.; Shenoy, B.D. First report of Colletotrichum asianum causing mango anthracnose in South Africa. Plant Dis. 2015, 99, 725. [CrossRef]

29. Honger, J.O.; Offei, S.K.; Oduro, K.A.; Odamtten, G.T.; Nyaku, S.T. Identification and species status of the mango biotype of Colletotrichum gloeosporioides in Ghana. Eur. J. Plant Pathol. 2014, 140, 455-467. [CrossRef] 
30. James, R.S.; Ray, J.; Tan, Y.P.; Shivas, R.G. Colletotrichum siamense, C. theobromicola and C. queenslandicum from several plant species and the identification of C. asianum in the Northern Territory, Australia. Australas. Plant Dis. Notes 2014, 9, 138. [CrossRef]

31. Krishnapillai, N.; Wilson Wijeratnam, R.S. First report of Colletotrichum asianum causing anthracnose on Willard mangoes Sri Lanka. New Dis. Rep. 2014, 29, 1. [CrossRef]

32. Mo, J.; Zhao, G.; Li, Q.; Solangi, G.S.; Tang, L.; Guo, T.; Huang, S.; Hsiang, T. Identification and characterization of Colletotrichum species associated with mango anthracnose in Guangxi, China. Plant Dis. 2018, 102, 1283-1289. [CrossRef]

33. Prihastuti, H.; Cai, L.; Chen, H.; McKenzie, E.H.C.; Hyde, K.D. Characterization of Colletotrichum species associated with coffee berries in northern Thailand. Fungal Divers. 2009, 39, 89-109.

34. Lima, N.B.; Lima, W.G.; Tovar-Pedraza, J.M.; Michereff, S.J.; Câmara, M.P.S. Comparative epidemiology of Colletotrichum species from mango in northeastern Brazil. Eur. J. Plant Pathol. 2015, 141, 679-688. [CrossRef]

35. Shivas, R.G.; Tan, Y.P.; Edwards, J.; Dinh, Q.; Maxwell, A.; Andjic, V.; Liberato, J.R.; Anderson, C.; Beasley, D.R.; Bransgrove, K.; et al. Colletotrichum species in Australia. Australas. Plant Path. 2016, 45, 447-464. [CrossRef]

36. Tivoli, B.; Baranger, A.; Avila, C.M.; Banniza, S.; Barbetti, M.; Chen, W.; Davidson, J.; Lindeck, K.; Kharrat, M.; Rubiales, D.; et al. Screening techniques and sources of resistance to foliar diseases caused by major necrotrophic fungi in grain legumes. Euphytica 2006, 147, 223-253. [CrossRef]

37. Litz, R.E. The Mango: Botany, Production and Uses, 2nd ed.; CAB International: Oxfordshire, UK, 2009; pp. 1-696.

38. Delgado, P.M.H.; Aranguren, M.; Reig, C.; Galván, D.F.; Mesejo, C.; Fuentes, A.M.; Saúco, V.G.; Agustí, M. Phenological growth stages of mango (Mangifera indica L.) according to the BBCH scale. Sci. Hortic. 2011, 130, 536-540. [CrossRef]

39. Tu, J.C. A detached leaf technique for screening beans (Phaseolus vulgaris L.) in vitro against anthracnose (Colletotrichum lindemuthianum). Can. J. Plant Sci. 1986, 66, 805-809. [CrossRef]

40. Iwaro, A.D.; Sreenivasan, T.N.; Umaharan, P. Foliar resistance to Phytophthora palmivora as an indicator of pod resistance in Theobroma cacao. Plant Dis. 1997, 81, 619-624. [CrossRef] [PubMed]

41. Bigirimana, J.; Höfte, M. Bean anthracnose: Inoculation methods and influence of plant stage on resistance of Phaseolus vulgaris cultivars. J. Phytopathol. 2001, 149, 403-408. [CrossRef]

42. Monteon-Ojeda, A.; Pérez-Rodriguez, A.; Mora-Aguilera, J.A.; Sandoval-Islas, J.S.; De-León-Garciá-De-Alba, C.; Hernández-Castro, E.; Vásquez-López, A. Evaluation of tolerance to vegetative anthracnosis of new mango germplasms in Mexico. Trop. Subtrop. Agroec. 2017, 20, 447-456.

43. Adikshita; Sharma, I.M.; Sharma, M. Screening of mango germplasm under natural epiphytotic conditions against anthracnose (Colletotrichum gloeosporioides). Indian Phytopathol. 2018, 71, 285-289. [CrossRef]

44. Giblin, F.R.; Tan, Y.P.; Mitchell, R.; Coates, L.M.; Irwin, J.A.G.; Shivas, R.G. Colletotrichum species associated with pre-and post-harvest diseases of avocado and mango in eastern Australia. Australas. Plant Path. 2018, 47, 269-276. [CrossRef]

45. Peterson, R.A. Mango diseases. In Proceedings of the CSIRO 1st Australian Mango Research Workshop; Chaplin, G.R., Ed.; CSIRO: Cairns, Australia, 1986; pp. 233-247.

46. Sharma, I.M.; Badiyala, S.D. Screening of mango cultivars for susceptibility to Colletotrichum gloeosporioides during different seasons. Indian Phytopathol. 1998, 51, 199-200.

47. Pernezny, K.; Ploetz, R. Some Common Diseases of Mango in Florida; University of Florida: Florid, FL, USA; Florida Cooperative Extension Service: Florid, FL, USA; Institute of Food and Agricultural Sciences: Florid, FL, USA, 2000; Available online: https://ufdcimages.uflib.ufl.edu/ (accessed on 2 September 2019).

48. Dinh, S.Q.; Chongwungse, J.; Pongam, P.; Sangchote, S. Fruit infection by Colletotrichum gloeosporioides and anthracnose resistance of some mango cultivars in Thailand. Australas. Plant Path. 2003, 32, 533-538. [CrossRef]

49. Donald, I. Constitutive Alk(en)ylresorcinols and resistance to postharvest disease in mango (Mangifera indica L.). Ph.D. Thesis, School of Agronomy and Horticulture, University of Queensland, Queensland, Australia, 2006.

50. Lei, X.T.; Zhao, Y.L.; Yao, Q.S.; He, Y.B.; Sun, G.M.; Ma, W.H.; Zhan, R.L. Identification and analysis of the resistance of different mango cultivars to anthracnose (Colletotrichum gloeosporioides). J. Fruit Sci. 2006, 6, 11.

51. Bhagwat, R.G.; Mehta, B.P.; Patil, V.A.; Sharma, H. Screening of cultivars/varieties against mango anthracnose caused by Colletotrichum gloeosporioides. Int. J. Environ. Agric. Res. 2015, 1, 21-23. 
52. O'Donnell, K.; Cigelnik, E. Two divergent intragenomic rDNA ITS2 types within a monophyletic lineage of the fungus Fusarium are non orthologous. Mol. Phylogenet. Evol. 1997, 7, 103-116. [CrossRef] [PubMed]

53. Glass, N.L.; Donaldson, G.C. Development of primer sets designed for use with the PCR to amplify conserved genes from filamentous ascomycetes. Appl. Environ. Microbiol. 1995, 61, 1323-1330. [CrossRef] [PubMed]

54. White, T.J.; Bruns, T.; Lee, S.; Taylor, J.W. Amplification and direct sequencing of fungal ribosomal RNA genes for phylogenetics. In PCR Protocols: A Guide to Methods and Applications; Innis, M.A., Gelfand, D.H., Sninsky, J.J., White, T.J., Eds.; Academic Press: San Diego, CA, USA, 1990; pp. 315-322.

55. Crous, P.W.; Groenewald, J.Z.; Risede, J.M.; Hywel-Jones, N.L. Calonectria species and their Cylindrocladium anamorphs: Species with sphaeropedunculate vesicles. Stud. Mycol. 2014, 50, 415-430.

56. Kumar, S.; Stecher, G.; Li, M.; Knyaz, C.; Tamura, K. MEGA X: Molecular evolutionary genetics analysis across computing platforms. Mol. Biol. Evol. 2018, 35, 1547-1549. [CrossRef]

57. Tamura, K. Estimation of the number of nucleotide substitutions when there are strong transition-transversion and G+C-content biases. Mol. Biol. Evol. 1992, 9, 678-687.

58. Tamura, K.; Nei, M. Estimation of the number of nucleotide substitutions in the control region of mitochondrial DNA in humans and chimpanzees. Mol. Biol. Evol. 1993, 10, 512-526.

59. Schneider, C.A.; Rasband, W.S.; Eliceiri, K.W. NIH Image to ImageJ: 25 years of image analysis. Nat. Methods 2012, 9, 671-675. [CrossRef]

60. Piccirillo, G.; Carrieri, R.; Polizzi, G.; Azzaro, A.; Lahoz, E.; Fernández-Ortuño, D.; Vitale, A. In vitro and in vivo activity of QoI fungicides against Colletotrichum gloeosporioides causing fruit anthracnose in Citrus sinensis. Sci. Hortic. 2018, 236, 90-95. [CrossRef]

61. Shah, D.A.; Madden, L.V. Nonparametric analysis of ordinal data in designed factorial experiments. Phytopathology 2004, 94, 33-43. [CrossRef] [PubMed]

(C) 2020 by the authors. Licensee MDPI, Basel, Switzerland. This article is an open access article distributed under the terms and conditions of the Creative Commons Attribution (CC BY) license (http://creativecommons.org/licenses/by/4.0/). 